\title{
Choline Kinase Alpha
}

National Cancer Institute

\section{Source}

National Cancer Institute. Choline Kinase Alpha. NCI Thesaurus. Code C25920.

Choline kinase alpha (457 aa, $\sim 52 \mathrm{kDa}$ ) is encoded by the human CHKA gene. This protein plays a role in phospholipid biosynthesis. 